\title{
REFRACTION SEISMIC INVESTIGATION AT ZEMU GLACIER, SIKKIM
}

\author{
By R. N. Bose, N. P. Dutta and S. M. Lahiri \\ (Geophysics Division, Geological Survey of India, 4 Prag Narain Road, Lucknow, India)
}

\begin{abstract}
Refraction seismic studies conducted on the Zemu Glacier in Sikkim at an altitude of $4570 \mathrm{~m}$ ( $15000 \mathrm{ft}$ ), indicate that the thickness of the glacier ice varies from about $125 \mathrm{~m}$ at the edge of the glacier to about $300 \mathrm{~m}$ at the centre. The bedrock section across the glacial valley as drawn on the basis of the seismic data corroborates the fact that the glacier has undergone considerable lateral shrinkage. The observed seismic velocity in the glacier ice, which ranges between $3500 \mathrm{~m} / \mathrm{s}$ and $3700 \mathrm{~m} / \mathrm{s}$ is in good agreement with the values obtained on glaciers in various parts of the world.

RÉsumÉ. Investigations par refraction sismique au Zemu Glacier dans le Sikkim. Des études par refraction sismique conduites sur le Zemu Glacier dans le Sikkim à une altitude de $4570 \mathrm{~m}$ indiquent que l'épaisseur de la glace varie depuis environ $125 \mathrm{~m}$ à la bordure du glacier jusqu'à environ $300 \mathrm{~m}$ au centre. Le profil de la section du bedrock à travers la vallée gláciaire dessiné sur la base des données sismiques corroborent le fait que le glacier a supporté un considérable retrécissement latéral. La vitesse de propagation de l'onde sismique dans la glace qui a été observée s'établie entre $3500 \mathrm{~m} / \mathrm{s}$ et $3700 \mathrm{~m} / \mathrm{s}$, ce qui concorde bien avec les valeurs obtenues sur les glaciers en divers points du monde.

Zusammenfassung. Refraktionsseimische Untersuchungen auf dem Zemu Glacier, Sikkim. Refraktionsseismische Untersuchungen, die auf dem Zemu Glacier in Sikkim in $4570 \mathrm{~m}$ Höhe durchgeführt wurden, ergeben, dass die Mächtigkeit des Gletschereises zwischen $125 \mathrm{~m}$ am Rande des Gletschers und $300 \mathrm{~m}$ in seiner Mitte schwankt. Ein aus seismischen Daten gezeichneter Querschnitt des Felsuntergrundes durch das Gletschertal bestätigt die Tatsache, dass der Gletscher eine beträchtliche seitliche Schrumpfung erfahren hat. Die beobachtete seismische Geschwindigkeit im Gletschereis, die zwischen $3500 \mathrm{~m} / \mathrm{s}$ und $3700 \mathrm{~m} / \mathrm{s}$ liegt, stimmt mit Werten, wie sie auf Gletschern in verschiedenen Teilen der Erde gefunden wurden, gut überein.
\end{abstract}

\section{INTRODUCTION}

An expedition was organised by the Geological Survey of India in April-May 1965 in the eastern Himalaya to study the features of the Zemu Glacier, the largest glacier in Sikkim. The paper presents the results of the refraction seismic surveys over the glacier. The work is a pioneering one in the sense that this was the first time that such studies had been undertaken in this country.

The glacier was first visited in $189 \mathrm{r}$ by Claude White, Political Officer in Sikkim and T. J. Hoffman, a well-known photographer in Calcutta. The glacier was again visited by D. W. Freshfield in the year I899 and by LaTouche (I9ro) in I9o9. Their studies were mainly confined to the general features of the glacier.

General features of the glacier. A detailed account of the glacier has been given by LaTouche (I9I0). The Zemu Glacier is about $25 \mathrm{~km}$ long with an average width of $\mathrm{I} \mathrm{km}$. It originates from the eastern flank of Kanchenjangha ridge, and, flowing in an easterly direction, also drains the northern slope of Simvo and Sinialchu. A very interesting feature associated with the glacier is the presence of trenches on the northern and southern sides of the glacier between the lateral moraine ridges and the rock wall (Fig. I). According to LaTouche (i9ro) lateral shrinkage of the glacier has given rise to these trenches.

The average slope of the glacier is I : ro towards the east. The surface of the glacier is very rugged and the ice surface is completely obscured under moraine (Fig. 2). The ruggedness of the glacier surface seems to persist as far as the foot of the precipices below Kanchenjangha as was stated in the account of Freshfield and Hoffman (LaTouche, igro). The presence of boulders on the surface made it impossible to auger holes for the placement of charge for the seismic work. Fortunately, small pools of water which were often observed in the depressed zones of the glacier surface could be utilised for this purpose.

At the time of LaTouche's visit, the snout of the glacier was located at an altitude of about $4000 \mathrm{~m}$. No ancient terminal moraine was observed by him, but he believed that the 


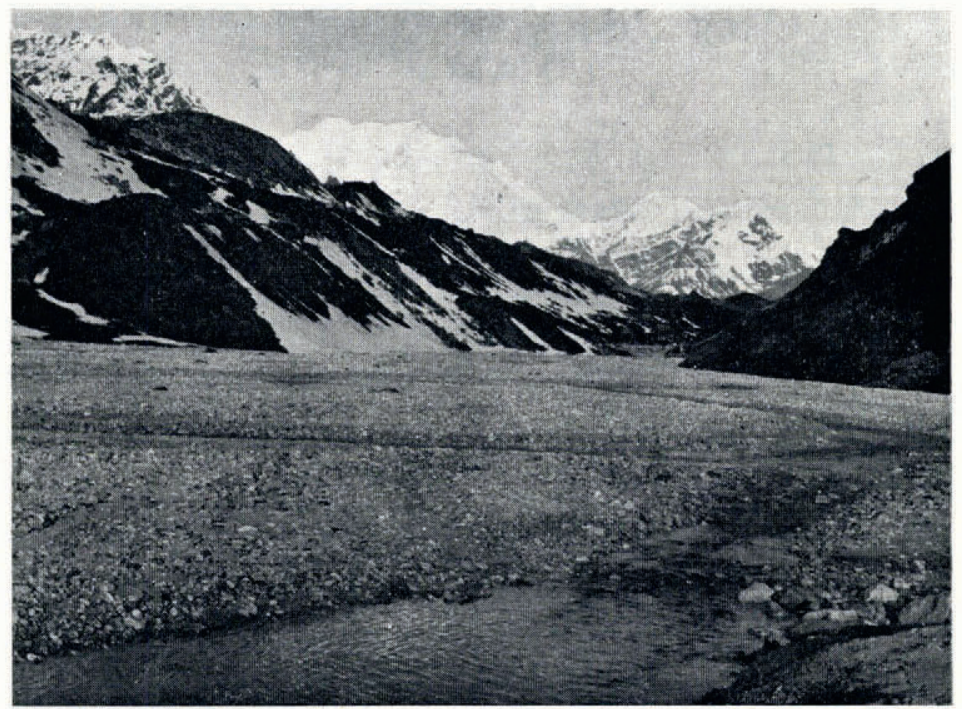

Fig. I. Northern trench between lateral moraine ridge (left) and rock wall (right).

glacier had probably extended a good deal further down. At the time of this expedition the snout was observed as a vertical ice cliff devoid of any boulders (Fig. 3) and seems to have retreated by at least $300 \mathrm{~m}$ since the time of LaTouche's visit.

\section{SEISMIC SURVEY}

Field procedure. A twelve-channel portable Century Refraction Seismograph was used for the seismic investigation. Long-range shooting was carried out by a telephone wire through a relay unit and a shooting attachment which were devised and constructed in the geophysical workshop of the Geological Survey of India.

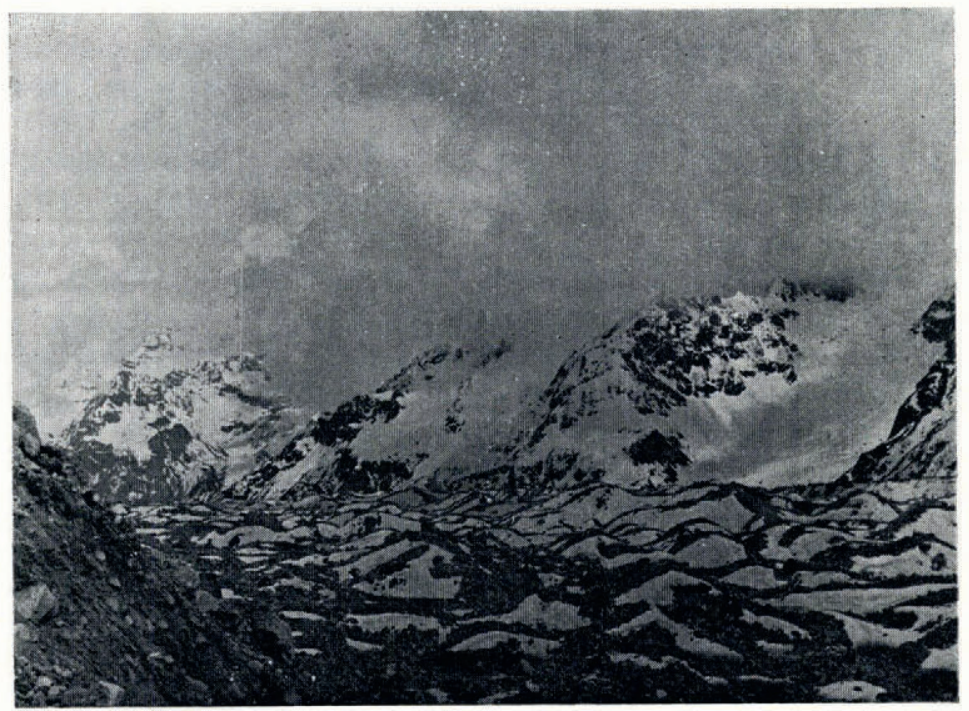

Fig. 2. Rugged surface of Zemu Glacier covered with morainic material. 


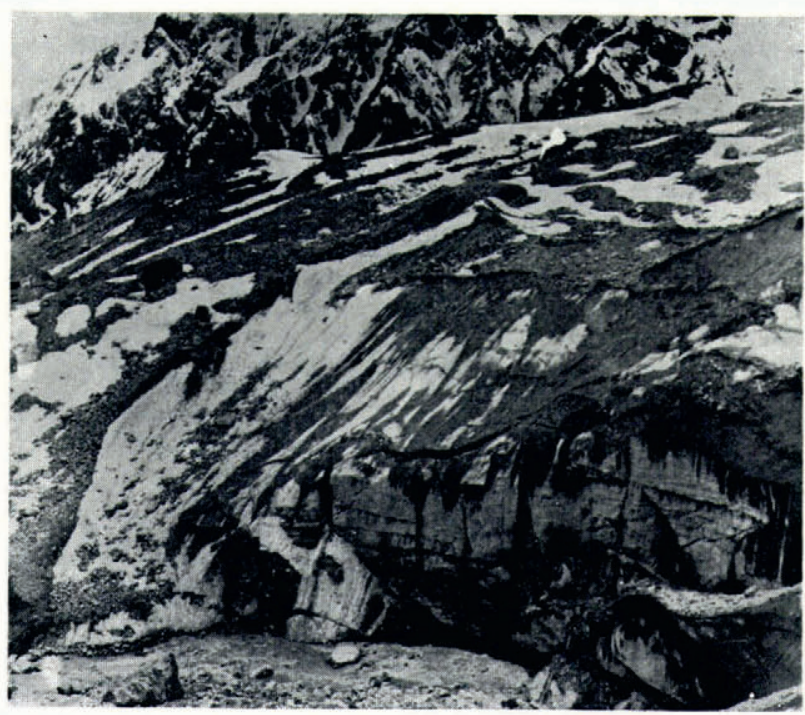

Fig. 3. The snout of Zemu Glacier.

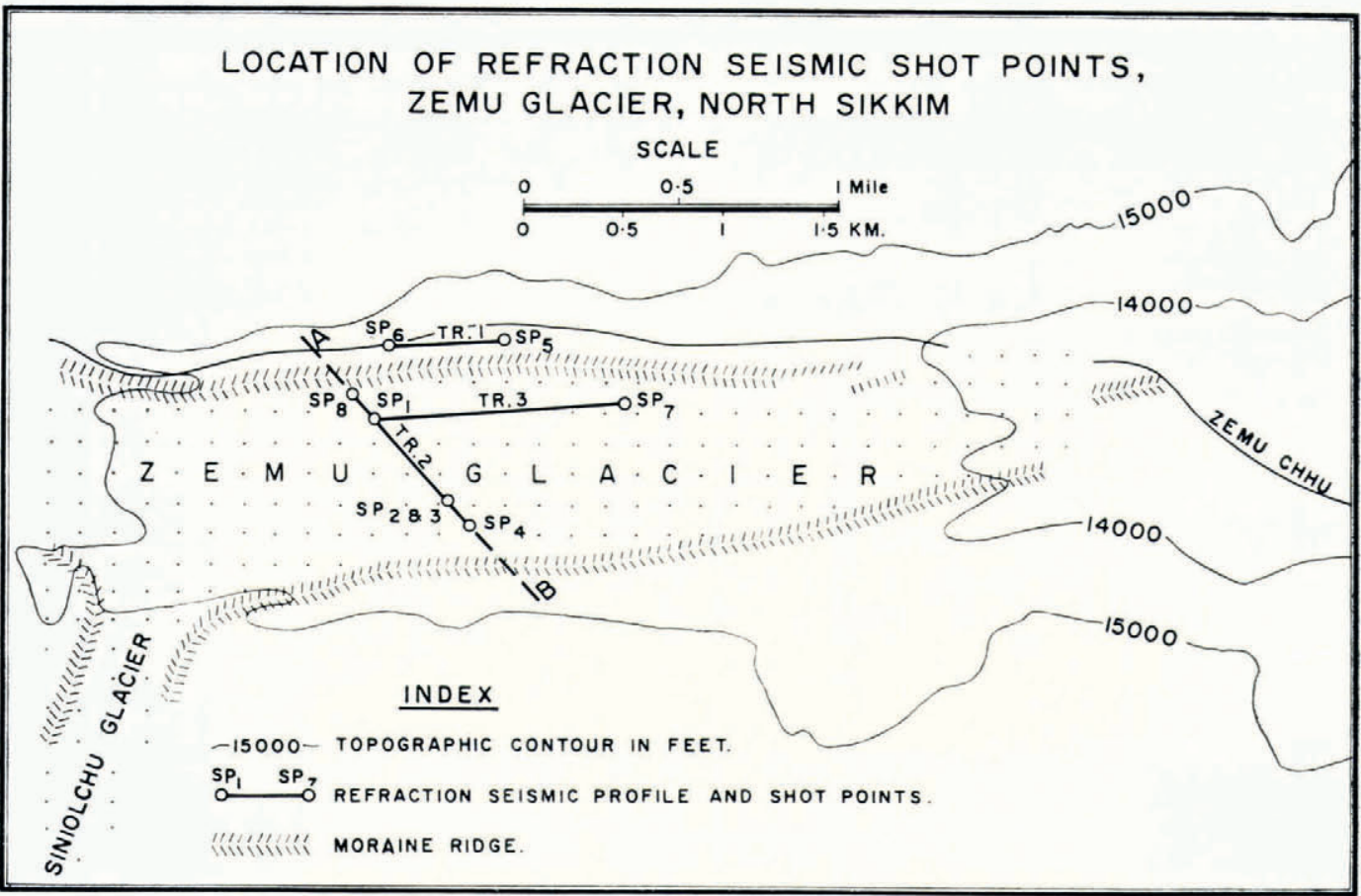

Fig. 4. Location of refraction seismic shot points, Zemu Glacier, north Sikkim. 


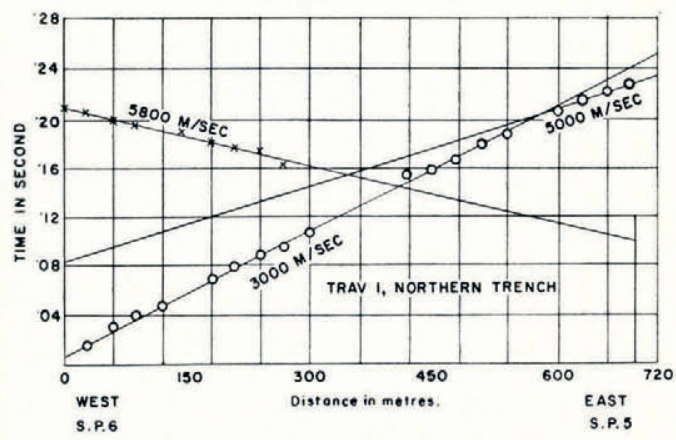

Fig. 5. Travel-time curve for traverse $\mathrm{I}$.

Refraction seismic studies were carried out at an average elevation of $4500 \mathrm{~m}$ and at a site $5 \mathrm{~km}$ west of the snout. Three major traverse alignments were chosen for refraction shooting (Fig. 4). Traverse I was located along the northern trench by the side of the glacier. The alignment of the other two traverses over the glacier was determined by the ruggedness of the terrain (the choice being along the direction of least undulation) and availability of water pools for shooting. The maximum profile lengths of traverses I, 2, 3 were respectively 720,870 and I $380 \mathrm{~m}$. The geophone spacing was maintained at $30 \mathrm{~m}$; the spread consisting of 12 geophones was moved in tandem along the traverse keeping the shot point fixed. However, in carrying out the seismic shooting some intermediate spreads were skipped off, in view of the limited time available. Attempts were mainly focused towards picking up the bedrock velocity.

Figure 5 presents the travel-time curve for profile 1 , shot in the northern trench. S.P.6, which was shot with a total spread of $720 \mathrm{~m}$ indicates a bedrock velocity of $5000 \mathrm{~m} / \mathrm{s}$ and a

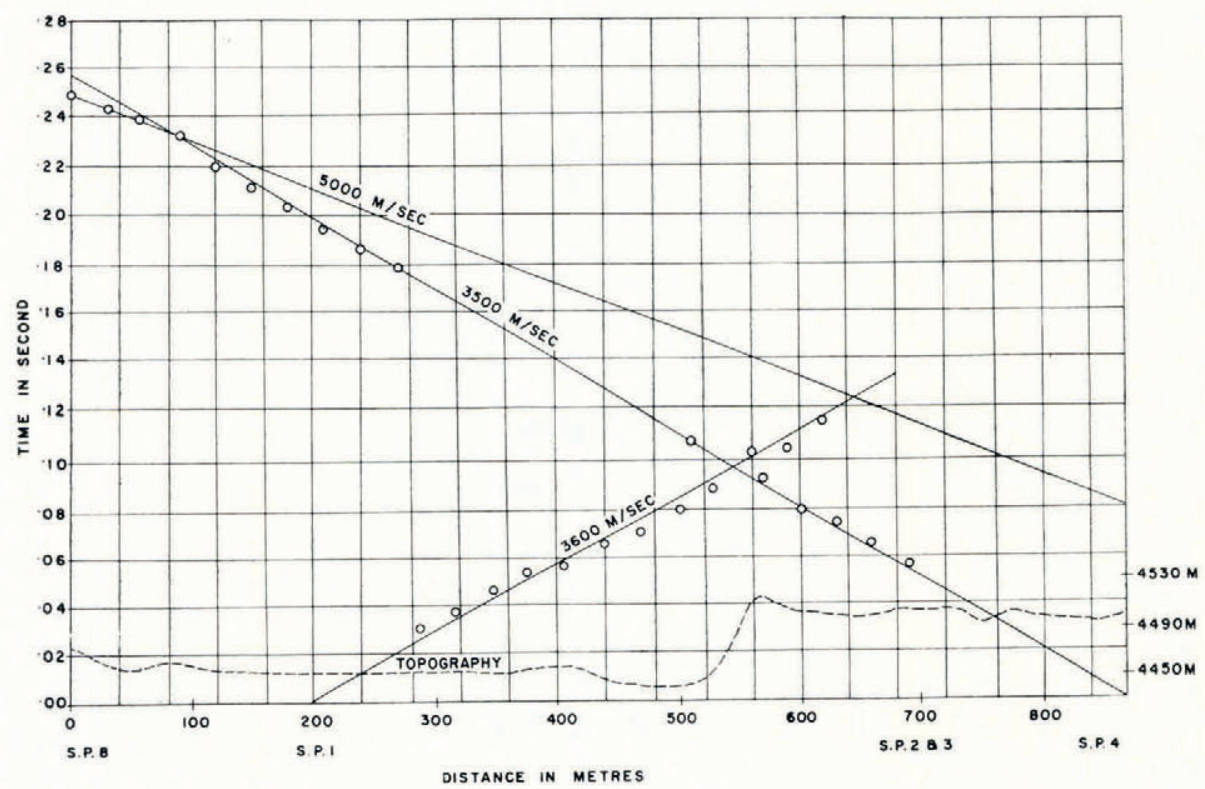

Fig. 6. Travel-time curve for traverse 2. 
velocity of $3000 \mathrm{~m} / \mathrm{s}$ for the intermediate layer. The reversed profile (S.P.5) shot only with one spread between 390 and $690 \mathrm{~m}$ shows a bedrock velocity of $5800 \mathrm{~m} / \mathrm{s}$. From a consideration of this travel-time curve a bedrock velocity of $5400 \mathrm{~m} / \mathrm{s}$ was adopted for all depth estimations. Depth estimates by the intercept time method indicate a bedrock depth of I $48 \mathrm{~m}$ at S.P.6. The approximate bedrock depth at S.P.5 is estimated to be ${ }^{5} 8 \mathrm{~m}$.

Over the glacier, the first profile shot with the shot point at S.P.I and a total spread length of $480 \mathrm{~m}$ failed to pick up the bedrock velocity. The time-distance curve (Fig. 6) indicates a velocity of $3600 \mathrm{~m} / \mathrm{s}$ for the glacier ice. The reversed profile with the shot point at S.P.2 and 3 and spreads extending up to S.P.I and S.P.8 respectively (Fig. 4) also did not indicate the bedrock velocity. The shot point when shifted further to S.P.4 and shot with a spread

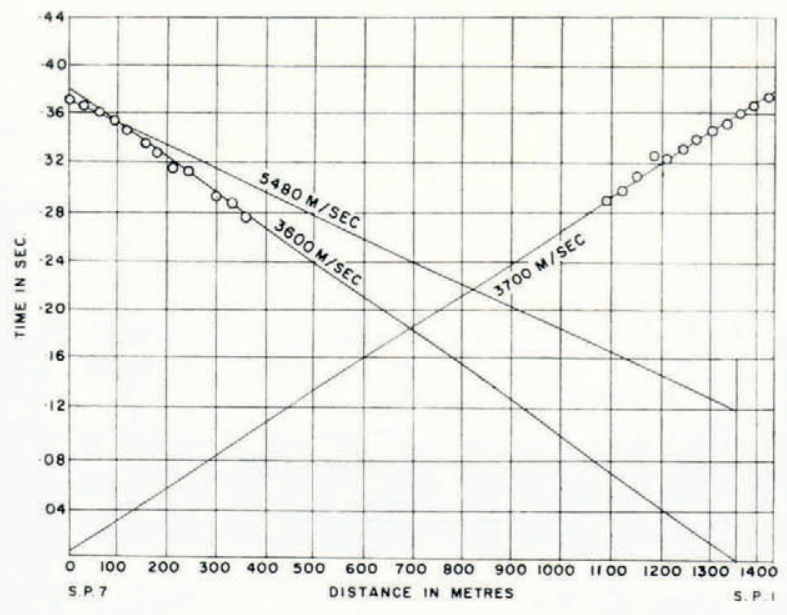

Fig. 7. Travel-time curve for traverse 3 .

length of $870 \mathrm{~m}$ (extending up to S.P.8) indicated a bedrock velocity of $5000 \mathrm{~m} / \mathrm{s}$ (Fig. 6). The depth to bedrock of $125 \mathrm{~m}$ is estimated at S.P.4 by the delay-time method, the depth to bed rock at S.P. I being known to be $280 \mathrm{~m}$. The bedrock depth at S.P. I has been determined from the results of shooting along Traverse 3 with a spread length of I $380 \mathrm{~m}$, the critical distance being at I $270 \mathrm{~m}$ (Fig. 7). Reversed shooting at S.P.7 employing a similar spread length failed to record the bedrock velocity. The depth estimate at S.P.I employing the critical distance was done with the assumption that the bedrock surface runs approximately parallel to the average surface topography along this profile.

\section{DisGuSSION OF RESULTS}

Analysis of the time-distance curve obtained from the first arrivals of the refraction seismograms indicate the velocities for the different formations given in Table I.

TABle I. Seismic Velocities in Different formations

Material

Bedrock (granite-gniess, augen-gneiss etc.)

Glacial ice

Sediment (hill wash and epi-glacial material filling up the northern trench)

Moraine materials on the surface of the surface of the glacier

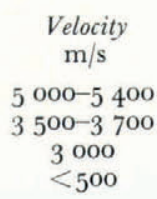

Velocity

5 000-5 400

500-3 700

$<500$ 
It was evident from a few vertical sections of the glacier ice underlying the morainic material, as well as from a study of the travel-time curves, that the surface ruggedness of the glacier (Fig. 2) is due more to the undulation of the glacier ice surface itself than to the disposition of the huge boulders. In the time-distance curve presented in Fig. 6, uncorrected times as plotted against horizontal distance fall almost on a straight line showing the velocity in glacier ice, in spite of the fact that there is an abrupt change in the elevation exceeding $5^{\circ} \mathrm{m}$ along this traverse. In general, the thickness of the loose morainic material on the top of the glacier ice does not seem to exceed 5 to $10 \mathrm{~m}$, as can be inferred from the analysis of the time-distance curves in Fig. 8. This short profile was shot $300 \mathrm{~m}$ to the west of S.P.7 on the relatively flat top of a surface moraine ridge. This profile was shot with the primary objective of determining the velocity of the surface morainic material, as the general topographic features around gave an apparent impression that the thickness of moraines at this location would be appreciably large, but an examination of the time-distance curve indicates that even the first geophone placed at a distance of $5 \mathrm{~m}$ from the shot point fell on the velocity segment for ice. This exemplifies that the top veneer of surface moraines is generally very thin and that the velocity in the surface moraines does not exceed $500 \mathrm{~m} / \mathrm{s}$.

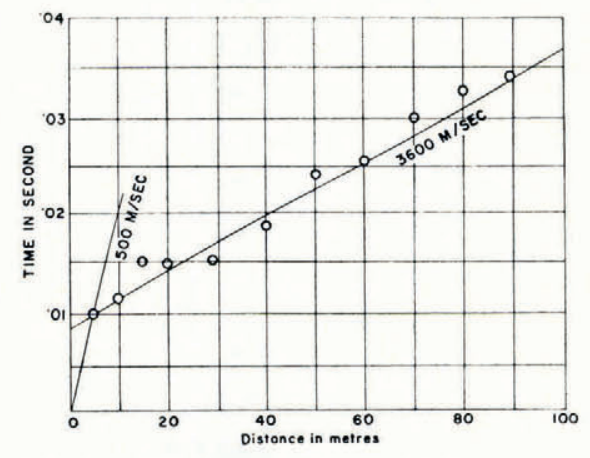

Fig. 8. Travel-time curve over moraines on the glacier.

The velocity of $3500-3700 \mathrm{~m} / \mathrm{s}$ as is observed for the glacier ice is in good agreement with the values obtained on glaciers in various parts of the world (Robin, r953; Hobson, I962).

A consideration of the time-distance curve for profile $\mathrm{I}$, in the northern trench (Fig. 5) indicates that the bedrock is overlain by sediments showing a velocity considerably lower than that of the glacier ice. This velocity of the order of about $3000 \mathrm{~m} / \mathrm{s}$, which is no doubt high for unconsolidated sediments, is due possibly to the abundance of boulders.

The critical distance corresponding to the interface between the glacier ice and the bedrock was very large, not only due to the large depth to the interface, but also due to the low velocity contrast between these two layers. It is evident, therefore, that the success of such a survey is entirely dependent on the type of bedrock present.

Figure 9 shows the bedrock section across the glacial valley along the line AB (Fig. 4) as drawn on the basis of the seismic data. In drawing this section the position of the lateral moraine ridges and the exposures (rock wall) at $\mathrm{A}$ and $\mathrm{B}$ have also been taken into consideration. The valley has its maximum depth at the centre where the thickness of glacier ice exceeds $300 \mathrm{~m}$. The section suggests that the glacier once occupied the entire valley, extending from the northern to the southern rock walls, and that it has undergone considerable lateral shrinkage giving rise to the northern and southern trenches. Subsequent movement of the 
glacier confined by the lateral moraine ridges has eroded the bedrock to a greater extent in the central zone than that underlying the trenches from which the glacier has receded to its present position.

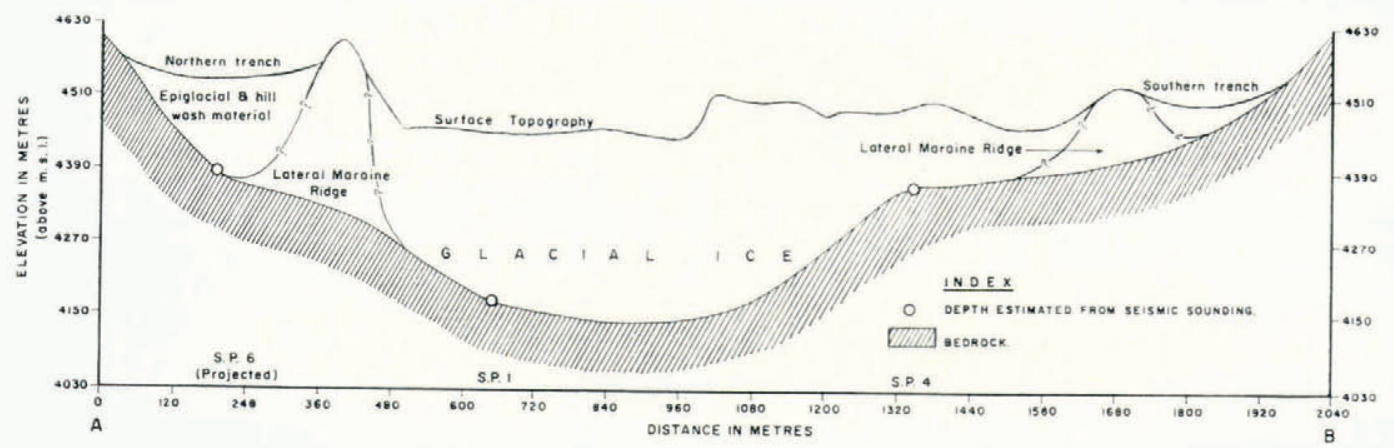

Fig. 9. Section of Zemu Glacier along traverse $A B$.

\section{Conclusion}

The investigation was conducted as a test case to study the feasibility and suitability of seismic operations on the glacier. In spite of limited facilities available the results of the seismic studies are significant.

\section{AckNOWLedgements}

The authors are grateful to the Director General, Geological Survey of India, for his kind permission to publish this paper.

MS. received 19 August 1969 and in revised form II September 1970

\section{REFERENCES}

Hobson, G. D. I962. Seismic exploration in the Canadian Arctic islands. Geophysics, Vol. 27, No. 2, p. $253-73$.

LaTouche, T. H. D. 1910. Notes on certain glaciers in Sikkim. Records of the Geological Survey of India, Vol. 40 , Pt. I, p. 52-62.

Robin, G. de Q. 1953. The Norwegian-British-Swedish Antarctic Expedition 1949-52. II. Summary of seismic shooting investigations in Dronning Maud Land. Journal of Glaciology, Vol. 2, No. 13, p. $205^{-1}$ I. 